\title{
In-vitro development of the rat parietal yolk sac
}

\author{
S. K. L. Ellington and D. A. T. New \\ Physiological Laboratory, University of Cambridge, Cambridge CB2 3EG, U.K.
}

\begin{abstract}
Summary. Rat embryos were cultured with the parietal yolk sac and other membranes intact. The development of the parietal yolk sac after $24 \mathrm{~h}$ in vitro was assessed by (1) the increase in size, (2) the morphology of the cellular components, and (3) the development of the embryo within the yolk sac. Development in vitro most resembled that in vivo when the embryos and membranes were explanted and cultured in rat serum diluted 1:1 with Hanks' or Waymouth's medium. High levels of oxygen were also beneficial. Culture in undiluted serum or under low oxygen concentrations resulted in very poor expansion of the yolk sac, abnormal trophoblastic giant cell morphology and stunted embryonic development.
\end{abstract}

\section{Introduction}

Little is known about either the role of the rodent parietal yolk sac in embryogenesis or the factors which regulate its growth. It is inaccessible for experimental manipulation in vivo and tends to grow abnormally when transplanted to other sites or grown in vitro. Culture conditions have now been established which support excellent growth of the embryo and the visceral yolk sac after removal of the parietal yolk sac (New, 1978), but if the parietal yolk sac is left intact it fails to expand and constricts the developing embryo and embryonic membranes (Jolly \& Lieure, 1938; Payne \& Deuchar, 1972). Isolated sheets of parietal yolk sac, with or without the trophoblast cells, also show abnormal growth in vitro; secretion of Reichert's membrane continues but it merely becomes thicker and fails to expand (Minor, Hoch, Koszalka, Brent \& Kefalides, 1976).

This paper describes a series of experiments designed to establish a method of culturing the parietal yolk sac as an intact membrane around the developing embryo, and to examine some of the factors affecting its growth.

\section{Materials and Methods}

Embryos and serum samples were obtained from CFHB or Wistar rats. At $10 \frac{1}{2}$ days post coitum each pregnant rat was anaesthetized in ether vapour, the abdominal cavity opened and blood collected from the dorsal aorta. The gravid uterine horns were removed and the embryos with their surrounding membranes (explants) were carefully dissected out of the enveloping decidua. The explanting medium was Hanks' solution or rat serum diluted 1:1 with Hanks' solution prepared as described by Paul (1975). All dissections were done at room temperature.

The explants and culture medium ( $1 \mathrm{ml} /$ explant) were usually incubated in $60-\mathrm{ml}$ bottles rotated on rollers at $38^{\circ} \mathrm{C}$ for $24 \mathrm{~h}$ (New, Coppola \& Terry, 1973). The bottles were gassed with the appropriate gas mixture at the start of the experiment, and again after culture for 10 and 20 h. In Exp. 4 explants were cultured in a system of rotating bottles through which the gas flow 
was continuous (New \& Cockroft, 1979). The gas mixture contained $\mathrm{O}_{2}$ adjusted as required, with $5 \% \mathrm{CO}_{2}$, and the remainder $\mathrm{N}_{2}$.

The culture medium was rat serum, either undiluted or diluted 1:1 with Hanks' solution or Waymouth's medium (Flow Laboratories Ltd). The serum was prepared from blood centrifuged immediately after extraction (Steele, 1972), and heat-inactivated at $57^{\circ} \mathrm{C}$ for $30 \mathrm{~min}$. Streptomycin and penicillin were added at $50 \mu \mathrm{g} / \mathrm{ml}$.

\section{Cultures}

Four series of cultures were made. In Exp. 1, explants were dissected out in Hanks' solution and cultured in undiluted serum (prepared from virgin female rats) under a gas phase containing $20 \% \mathrm{O}_{2}$. These conditions, 'standard' embryo culture conditions, have been shown to support excellent growth and differentiation of similar stage embryos with an intact visceral yolk sac but without the parietal yolk sac (New, Coppola \& Cockroft, 1976).

In Exps 2, 3 and 4, the effects of different explanting media, of different culture sera, of diluting the sera and of changing the $\mathrm{O}_{2}$ level, were examined (see 'Results').

\section{Assessment of cultures}

At the end of each culture all explants were examined for heartbeat and blood circulation in the visceral yolk sac, for rotation of the embryo to the fetal position and for any gross abnormalities.

At $10 \frac{1}{2}-11 \frac{1}{2}$ days the explant is approximately spherical. Before and after culture the maximum and minimum diameters of the explant were measured. The surface area of the parietal yolk sac was calculated as the surface area of a sphere of diameter equal to the mean of the two measurements.

The explants were then fixed for at least 2 days in Bouin's fluid. In-vivo controls (embryos and their membranes inside the intact decidua) were also fixed. Standard techniques were used for dehydration, embedding in wax, sectioning and staining with haemalum and eosin.

\section{Results}

Morphology of the parietal yolk sac: in-vivo controls

At $10 \frac{1}{2}$ days the parietal yolk sac was about $20 \mathrm{~mm}^{2}$ in area and surrounded all the conceptus except the ectoplacental cone. The middle layer, Reichert's membrane, was about $1 \mu \mathrm{m}$ thick. The parietal endoderm was composed of small discrete cells scattered over the entire inner surface of the membrane; some of these cells showed mitotic figures. The elongate trophoblastic giant cells did not divide but migrated from the ectoplacental cone to form a cellular mesh around Reichert's membrane. At $10 \frac{1}{2}$ days the meshwork extended over about $25-35 \%$ of the surface of the membrane. Maternal blood filled the spaces in the trophoblast meshwork and bathed the outer surface of Reichert's membrane (Pl. 1, Fig. 1).

By $11 \frac{1}{2}$ days the area of the parietal yolk sac had increased to about $75 \mathrm{~mm}^{2}$, and Reichert's membrane had thickened to a maximum of $1.5 \mu \mathrm{m}$. The parietal endoderm cells had become more closely packed, especially at the antimesometrial pole of the conceptus (Pl. 2, Fig. 4). The trophoblast cell layer extended to cover $50-75 \%$ of Reichert's membrane.

\section{Experiment 1: 'standard' embryo culture conditions}

After $24 \mathrm{~h}$ in culture under 'standard' conditions, the explants had not expanded, and many were smaller than at explanation. The cellular structure of the parietal yolk sac was unlike that of 

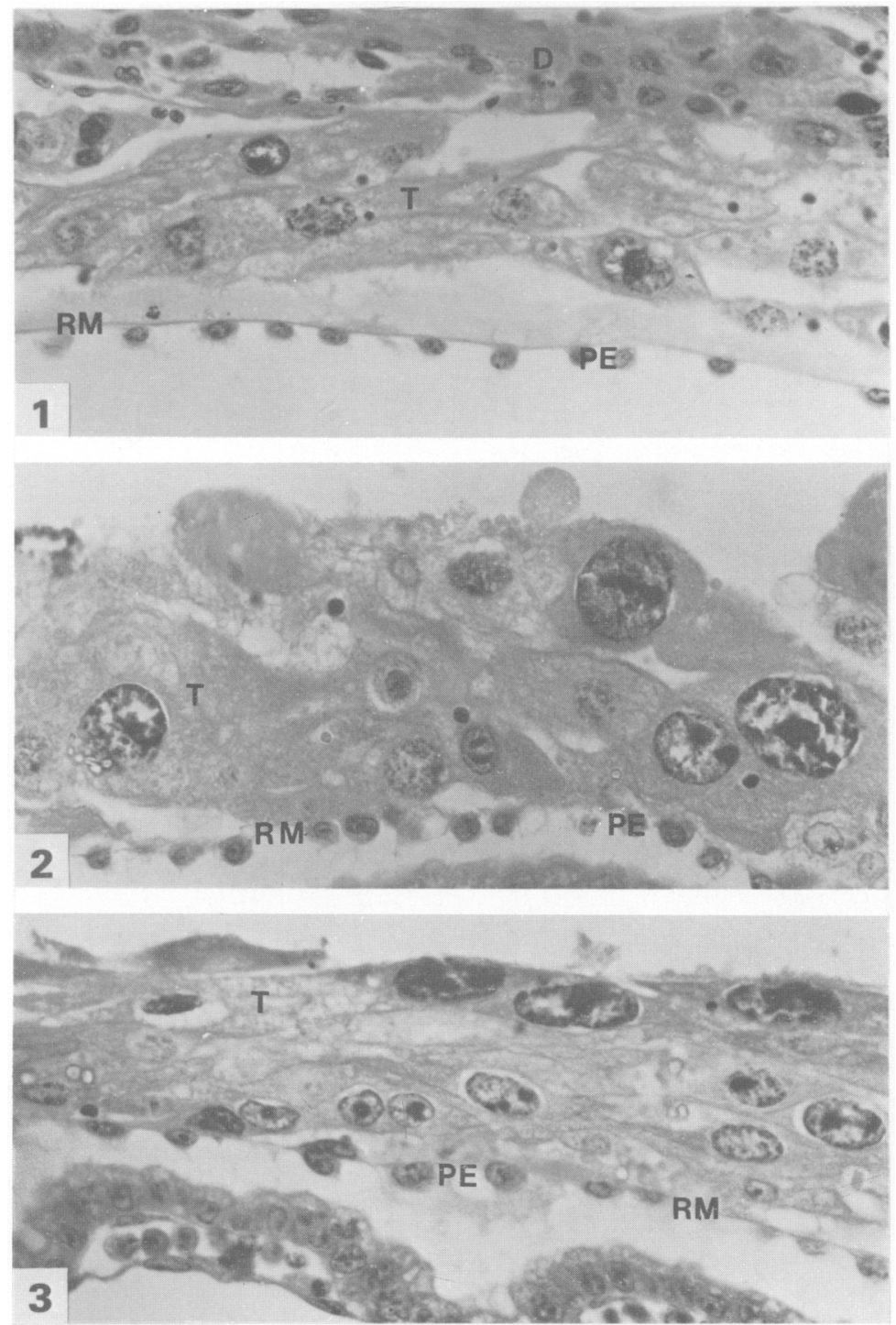

Sections of wax-embedded specimens stained with haemalum and eosin. Each photograph is taken from a similar area of the explant, just antimesometrial to the allantoic placenta. D, decidual cells; T, trophoblast cells; RM, Reichert's membrane; PE, parietal endoderm cells.

Fig. 1. The parietal yolk sac of a $10 \frac{1}{2}$ day control embryo (in vitro). $\times 400$.

Fig. 2. The parietal yolk sac of a $10 \frac{1}{2}$ day embryo after explantation in Hanks' solution. $\times 400$.

Fig. 3. The parietal yolk sac of a $10 \frac{1}{2}$ day embryo after explanation in $50 \%$ serum $/ 50 \%$ Hanks' solution. $\times 400$. 

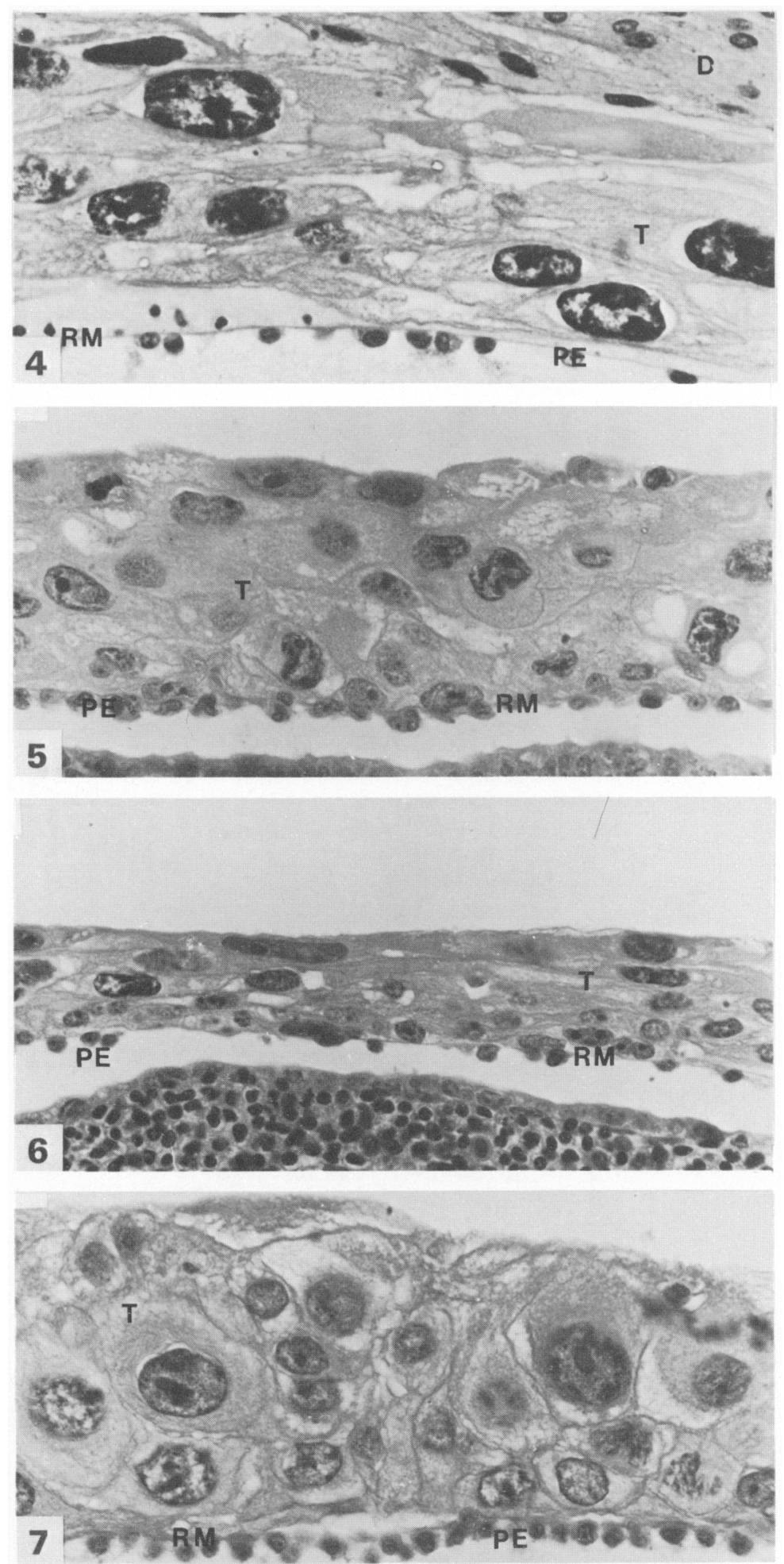
embryos of equivalent age (11 $\frac{1}{2}$ days) in vivo. The parietal endoderm cells (which had continued to divide) were abnormally closely packed, especially at the antimesometrial pole of the explant where they formed several layers. The trophoblast had changed to rounded, compact cells with vacuolated cytoplasm.

Few embryos showed any development in culture. By the end of the culture period none of the embryos had rotated and most contained a high proportion of necrotic cells. (In comparison, over $90 \%$ of embryos cultured without the parietal yolk sac during this period of development would show complete rotation, normal growth and a functioning blood circulation (New, 1978).)

\section{Experiment 2: modification of explanting medium}

The explanting medium did affect the morphology of the trophoblast cells. Within 30 min of immersion of the explants in Hanks' solution the trophoblast cells became rounded with vacuolated cytoplasm and reduced inter-cellular spaces (Pl. 1, Fig. 2). Similar results were obtained from explants dissected in Tyrode's solution or $0.9 \% \mathrm{NaCl}$. In contrast, when a mixture of $50 \%$ serum $/ 50 \%$ Hanks' solution was used as the explanting medium the trophoblast cells retained their normal in-vivo appearance (Pl. 1, Fig. 3). However, the effect of the explanting medium on subsequent development in culture was small. The explants explanted in the serum:Hanks' solution developed and expanded slightly more than those explanted in Hanks' alone but the difference in increase in surface area of the parietal yolk sac was not significant $(0.05<P<0 \cdot 1$, Student's $t$ test $)$.

\section{Experiment 3: modification of culture medium}

Table 1 summarizes the results of culturing explants in either $100 \%$ serum or serum diluted to $50 \%$ with Hanks' solution. The sera were from mature male rats, non-pregnant females or $10 \frac{1}{2}$ day pregnant females. Overall, those explants cultured in diluted serum showed a greater increase in the area of the parietal yolk sac $(P<0.02$, Student's $t$ test) and better embryonic development than did those in undiluted serum. There was, however, considerable individual variation in development; in most cultures some explants failed to expand at all while others developed well. The causes of such variability were not apparent.

The morphology of the parietal yolk sac also remained more similar to normal in the diluted serum. Although the inter-cellular spaces of the trophoblast were reduced, the trophoblast cells remained elongated with long cytoplasmic processes and granular cytoplasm; the parietal endoderm cells and Reichert's membrane also appeared similar to those of in-vivo controls. In $100 \%$ serum, the trophoblast cells became rounded and vacuolated, and formed a thick compact layer closely attached to Reichert's membrane, the endoderm cells became abnormally crowded (Pl. 2, Fig. 5). No significant differences were found with the different types of serum (Table 1).

\section{PLATE 2}

Sections of wax-embedded specimens stained in haemalum and eosin. Each photograph is taken from a similar area of the explant, just antimesometrial to the allantoic placenta. D, decidual cells; T, trophoblast cells; RM, Reichert's membrane; PE, parietal endoderm cells.

Fig. 4. The parietal yolk sac of an $11 \frac{1}{2}$ day control embryo (in vivo). $\times 400$

Fig. 5. The parietal yolk sac after explanation at $10 \frac{1}{2}$ days and culture for $24 \mathrm{~h}$ in $100 \%$ serum under a gas phase containing $20 \% \mathrm{O}_{2} \times 400$.

Fig. 6. The parietal yolk sac after explantation at $10 \frac{1}{2}$ days and culture for $24 \mathrm{~h}$ in $50 \%$ serum $/ 50 \%$ Waymouth's medium under a gas phase in which the oxygen concentration was increased from 20 to $40 \%$ at $10 \mathrm{~h}$ and then to $95 \%$ at $20 \mathrm{~h} . \times 400$.

Fig. 7. The parietal yolk sac after explantation at $10 \frac{1}{2}$ days and culture for $24 \mathrm{~h}$ in $50 \%$ serum $/ 50 \%$ Waymouth's medium under a gas phase containing $10 \%$ oxygen. $\times 400$. 
Table 1. Development of rat embryo explants cultured in $100 \%$ serum (from males, non-pregnant females and $10 \frac{1}{2}$ day-pregnant females) and in $50 \%$ serum $/ 50 \%$ Hanks' solution

\begin{tabular}{|c|c|c|c|c|c|c|c|}
\hline \multirow[b]{3}{*}{ Serum } & \multirow{3}{*}{$\begin{array}{l}\text { No. of } \\
\text { embryos }\end{array}$} & & & \multirow{3}{*}{$\begin{array}{c}\% \\
\text { Increase }\end{array}$} & \multicolumn{3}{|c|}{ No. (\%) of embryos } \\
\hline & & \multicolumn{2}{|c|}{$\begin{array}{c}\text { Mean } \pm \text { s.e.m. } \\
\text { surface area }\left(\mathrm{mm}^{2}\right)\end{array}$} & & \multirow{2}{*}{$\begin{array}{l}\text { With } \\
\text { heart } \\
\text { beat }\end{array}$} & \multirow{2}{*}{$\begin{array}{c}\text { With } \\
\text { visceral } \\
\text { yolk sac } \\
\text { circulation }\end{array}$} & \multirow{2}{*}{$\begin{array}{l}\text { Fully } \\
\text { rotated }\end{array}$} \\
\hline & & At start & At end & & & & \\
\hline $\begin{array}{l}100 \% \text { ठ } \\
100 \% \text { ○ } \\
100 \% \text { pregnant } \$\end{array}$ & $\begin{array}{l}21 \\
20 \\
21\end{array}$ & $\begin{array}{l}21.56 \pm 0.48 \\
21.67 \pm 0.60 \\
21.62 \pm 0.55\end{array}$ & $\begin{array}{l}21.75 \pm 1.08 \\
24.38 \pm 1.39 \\
21.43 \pm 1.15\end{array}$ & $\begin{array}{r}0.88 \\
12.50 \\
-0.94\end{array}$ & $\begin{array}{c}1(5) \\
10(50) \\
6(29)\end{array}$ & $\begin{array}{r}7(33) \\
15(75) \\
14(67)\end{array}$ & $\begin{array}{r}5(24) \\
12(60) \\
10(48)\end{array}$ \\
\hline Totals and means & 62 & $21.62 \pm 0.31$ & $* 22.49 \pm 0.70$ & $4 \cdot 02$ & $17(27)$ & $36(58)$ & $27(44)$ \\
\hline $\begin{array}{l}50 \% \text { ठ } \\
50 \% \text { \& } \\
50 \% \text { pregnant } q\end{array}$ & $\begin{array}{l}23 \\
41 \\
40\end{array}$ & $\begin{array}{l}20.07 \pm 0.51 \\
21.75 \pm 0.54 \\
21.97 \pm 0.57\end{array}$ & $\begin{array}{l}24.20 \pm 0.67 \\
26.08 \pm 1.10 \\
24.59 \pm 1.27\end{array}$ & $\begin{array}{l}20 \cdot 58 \\
19.91 \\
11.93\end{array}$ & $\begin{array}{l}12(52) \\
17(42) \\
11(28)\end{array}$ & $\begin{array}{l}21(91) \\
27(66) \\
19(48)\end{array}$ & $\begin{array}{l}14(61) \\
31(76) \\
24(60)\end{array}$ \\
\hline Totals and means & 104 & $21.46 \pm 0.33$ & $* 25.09 \pm 0.33$ & 16.92 & $40(39)$ & $68(65)$ & $69(66)$ \\
\hline
\end{tabular}

* Significantly different, $P<0.02$ (Student's $t$ test).

\section{Experiment 4: modification of the gas phase}

Explants were cultured in $50 \%$ serum $/ 50 \%$ Waymouth's medium under three different oxygen schedules: (i) $10 \% \mathrm{O}_{2}$ throughout, (ii) $5 \rightarrow 20 \rightarrow 40 \% \mathrm{O}_{2}$, (iii) $20 \rightarrow 40 \rightarrow 95 \% \mathrm{O}_{2}$. In (ii) and (iii) the changes were made after $10 \mathrm{~h}$ and $20 \mathrm{~h}$ of culture. The oxygen concentration was kept fairly low at first in all cultures because high oxygen concentrations are known to be harmful to the early embryo (New \& Coppola, 1970).

Only the explants cultured in the highest oxygen levels $(20 \rightarrow 40 \rightarrow 95 \%)$ showed any expansion of the parietal yolk sac (Table 2). The morphology of the parietal yolk sac was fairly normal, with elongated trophoblast cells, after culture in $20 \rightarrow 40 \rightarrow 95 \% \mathrm{O}_{2}$ or $5 \rightarrow 20 \rightarrow 40 \% \mathrm{O}_{2}$ (Pl. 2, Fig. 6), but in $10 \% \mathrm{O}_{2}$ throughout the culture period the trophoblast cells became rounded and compact, and Reichert's membrane thickened abnormally to $2.5-3.0 \mu \mathrm{m}$ (Pl. 2, Fig. 7).

Table 2. Development of rat embryo explants cultured under gas phases containing different oxygen concentrations

\begin{tabular}{|c|c|c|c|c|c|c|c|}
\hline \multirow{3}{*}{$\begin{array}{l}\text { Oxygen } \\
(\%)\end{array}$} & \multirow{3}{*}{$\begin{array}{l}\text { No. of } \\
\text { embryos }\end{array}$} & & & \multirow{3}{*}{$\begin{array}{c}\% \\
\text { Increase }\end{array}$} & \multicolumn{3}{|c|}{ No. (\%) of embryos } \\
\hline & & \multicolumn{2}{|c|}{$\begin{array}{c}\text { Mean } \pm \text { s.e.m. } \\
\text { surface area }\left(\mathrm{mm}^{2}\right)\end{array}$} & & \multirow{2}{*}{$\begin{array}{c}\text { With } \\
\text { heart } \\
\text { beat }\end{array}$} & \multirow{2}{*}{$\begin{array}{c}\text { With } \\
\text { visceral } \\
\text { yolk sac } \\
\text { circulation }\end{array}$} & \multirow{2}{*}{$\begin{array}{l}\text { Fully } \\
\text { rotated }\end{array}$} \\
\hline & & At start & At end & & & & \\
\hline 10 & 17 & $23.27 \pm 0.64$ & ${ }^{*} 19.35 \pm 1.05$ & $-16 \cdot 83$ & $2(12)$ & $0(0)$ & $4(26)$ \\
\hline $5 \rightarrow 20 \rightarrow 40$ & 17 & $22 \cdot 10 \pm 0.67$ & $\dagger 20.08 \pm 1.91$ & $-9 \cdot 12$ & $4(24)$ & $4(24)$ & $6(35)$ \\
\hline $20 \rightarrow 40 \rightarrow 95$ & 17 & $23.18 \pm 0.78$ & $*+30.27 \pm 0.78$ & $30 \cdot 59$ & $15(88)$ & $9(53)$ & $15(88)$ \\
\hline
\end{tabular}

* Significantly different, $P<0.001$ (Student's $t$ test).

† Significantly different, $P<0.001$ (Student's $t$ test).

\section{Discussion}

This paper shows that rat embryos can be grown in culture with the parietal yolk sac intact. Essential conditions are that the culture serum should be diluted (e.g. to $50 \%$ with Hanks' or Waymouth's medium) and the oxygen of the gasphase maintained at a high level $(20-695 \%)$. 
The tissue that appears to be most sensitive to the concentration of the serum is trophoblast. After culture in undiluted serum (or after brief immersion in medium without any serum) the trophoblast cells become abnormally rounded, vacuolated and tightly packed; in diluted serum, they retain the normal elongated shape similar to that found in vivo. This suggests that the failure of the parietal yolk sac to expand in undiluted serum probably follows from a primary change in the trophoblast and could be due to one of three possible mechanisms. (1) A direct effect of the abnormal trophoblast on the parietal endoderm cells. Histological examination suggests that this is unlikely. The endoderm cells appear normal (although crowded) and are continuing to secrete Reichert's membrane (which in the absence of expansion becomes unusually thick). (2) Reduced passage of fluid through the trophoblast. The continuous secretion of fluid into the amniotic and yolk sac cavities maintains an internal pressure which keeps the membranes from collapsing and may be necessary for the expansion of Reichert's membrane. If the passage of fluid through the trophoblast into the conceptus is reduced, the resulting fall in internal pressure might lead to a failure of expansion of the membrane. (3) Increased resistance of the trophoblast to expansion. The altered shape and cohesion of the cells in the abnormal trophoblast might be associated with increased resistance to expansion. This, possibly combined with reduced internal pressure, appears to us the most likely mechanism.

The need to dilute the culture serum is surprising. When embryos are grown without the parietal yolk sac, so that the visceral yolk sac is in contact with the medium, normal growth is obtained in undiluted serum (New, 1978). In the uterus, the conceptus is bathed by maternal blood, which might be supposed to resemble whole serum more than diluted serum. It may be the absence of decidual tissue in culture which favours diluted serum. The decidua has an important regulatory effect in vivo, and in its absence trophoblast growth is very abnormal (Kirby, 1970). Although part of the regulatory effect is probably the result of direct contact between the two tissues, the decidua may also change the composition of the maternal blood before it flows through the trophoblast tissue. Diluting culture serum may imitate some of these changes, particularly any removal of substrates from the maternal blood by the decidua.

The need for a high oxygen level is easier to explain. The parietal yolk sac has no fetal blood circulation and, although in the uterus oxygenated maternal blood circulates through the trophoblast spaces, in culture oxygen must pass through the full thickness of the parietal yolk sac before arriving at the fetal blood capillaries in the visceral yolk sac. Furthermore, the restricted expansion of the visceral yolk sac reduces the area for oxygen uptake and increases the demand for high oxygen levels.

As far as we know, this paper is the first report of successful growth and expansion of parietal yolk sac in culture. At present, growth is limited and much less than that shown during an equivalent period in vivo. It is also very variable from one embryo to another, for reasons that are not understood. However, many of the embryos remain alive and growing throughout the 24-h culture period and the culture system could be valuable for studies on the relation of the parietal yolk sac to embryo physiology and development. It also provides an opportunity to study the properties of a basement membrane (Reichert's membrane) under conditions much more amenable to experiment than those usually available.

We thank the Medical Research Council for financial support.

\section{References}

Jolly, J. \& Lieure, C. (1938) Recherches sur la culture des oeufs des mammifères. Archs Anat. microsc. 34, 307-374.

Kirby, D.R.S. (1970) The extra-uterine mouse egg as an experimental model. Adv. Biosci. 4, 255-273.

Minor, R.R., Hoch, P.S., Koszalka, T.R., Brent, R.L. \&
Kefalides, N.A. (1976) Organ cultures of the embryonic rat parietal yolk sac. 1. Morphological and autoradiographic studies on the deposition of the collagen and noncollagen glycoprotein components of basement membrane. Devl Biol. 48, 344Dow364aded from Bioscientifica.com at 04/26/2023 11:44:51AM 
New, D.A.T. (1978) Whole-embryo culture and the study of mammalian embryos during organogenesis. Biol. Rev. 53, 81-122.

New, D.A.T. \& Cockroft, D.L. (1979) A rotating bottle culture method with continuous replacement of the gas phase. Experientia 35, 138-139.

New, D.A.T. \& Coppola, P.T. (1970) Effects of different oxygen concentrations on the development of rat embryos in culture. J. Reprod. Fert. 21, 109-118.

New, D.A.T., Coppola, P.T. \& Terry, S. (1973) Culture of explanted rat embryos in rotating tubes. $J$. Reprod. Fert. 35, 135-138.
New, D.A.T., Coppola, P.T. \& Cockroft, D.L. (1976) Comparison of growth in vitro and in vivo of post-implantation rat embryos. J. Embryol. exp. Morph. 41, 111-123.

Paul, J. (1975) Cell and Tissue Culture, 5th edn. Churchill Livingstone, Edinburgh.

Payne, G.S. \& Deuchar, E.M. (1972) An in vitro study of functions of embryonic membranes in the rat. $J$. Embryol. exp. Morph. 27, 533-542.

Steele, C.E. (1972) Improved development of rat 'egg-cylinders' in vitro as a result of fusion of the heart primordia. Nature, New Biol. 237, 150-151.

Received 7 February 1980 